\title{
Medicinal plants for management and alternative therapy of common ailments in Dutsin-Ma (Katsina State) in Nigeria
}

\author{
IDRIS ZUBAIRU SADIQ ${ }^{1 *}$, FATIMA SADIQ ABUBAKAR ${ }^{1,2}$, BASHIRU IBRAHIM $^{1}$, \\ MOHAMMED ALIYU USMAN ${ }^{1}$, ZEENAT BELLO KUDAN ${ }^{1}$
}

\author{
${ }^{1}$ Department of Biochemistry \\ Faculty of Life Sciences \\ Ahmadu Bello University \\ Zaria, Nigeria \\ ${ }^{2}$ National Agricultural Extension and Liaison Services \\ Ahmadu Bello University \\ Zaria, Nigeria \\ *corresponding author: phone: +2348038041910, e-mail: idrisubalarabe2010@gmail.com
}

\section{Summary}

Introduction: Nowadays, many synthetic drugs comes with various degrees of side effects, accumulative toxicity and development of resistance by microorganisms. Medicinal plants used worldwide can be developed into modern drugs with little or no side effects and greater efficacy.

Objective: The aim of this paper was to document the alternative therapy used in Dutsin-Ma local community in Katsina state, Nigeria.

Methods: Ethnobotanical survey was carried out among 40 traditional herbalists. Out of 106 plants found, screening was conducted to include only plants that are prescribed simultaneously by the entire herbalists.

Results: We have found 32 species of medicinal plants from 20 families that are used for management and alternative therapy against common ailments such as malaria, diabetes, sickle cell anaemia, hypertension, ulcer, paralysis, typhoid fever and immune deficiency.

Conclusion: Traditional medicinal plants provide the alternative therapy for treatment and management of diseases to significant number of people. Herbal practitioners are still relevant to African healthcare system.

Key words: ethnobotanical survey, medicinal plants, traditional herbalist, common ailments, alternative therapy

Słowa kluczowe: badanie etnobotaniczne, rośliny zielarskie, zielarze ludowi, typowe schorzenia, terapia alternatywna 


\section{INTRODUCTION}

The search for the new plant-based therapies continues to rise globally due to the emergence of resistance to many conventional drugs. In Nigeria, people have been using traditional medicines for a long time for the treatment of many diseases. Knowledge on the use of traditional medicines is passed orally from elders to new generations. Generally in Africa, traditional medicinal plants have been used in the treatment and management of many diseases [1] including diabetes, sickle cell anaemia, common cold, flu, jaundice and hepatitis [2]. These therapies have become very popular in rural areas with little or no access to modern medicines and among poor people from the urban areas.

Many plants are good source of natural medicines and bioactive compounds participating in free radical scavenging activities owing to antioxidants. Carotenoids and polyphenols for example, exhibited many beneficial effects including anti-atherosclerosis, antiaging, anticancer and anti-inflammation [3]. The scavenging activity of these plants makes them excellent antioxidants participating in oxidation-reduction reactions in biological systems. Biologically active compounds from medicinal plants have become the subject of interest to western societies and many researchers have focused on the role of traditional medicines due to their safety and minimal side effects.

Medicinal plants have a number of applications other than medicinal and pharmaceutical uses. For instance, they are use as food, tea, perfume, pest-control, anti-insects and as a dyer.
The aim of this paper is to document the alternative therapy used in Dutsin-Ma local community in Katsina state, Nigeria.

\section{METHODOLOGY}

Ethnobotanical survey of medicinal plants was conducted involving 40 traditional medical herbalists. Herbalists were selected based on location (study area) and professionalism. They were interviewed orally at various locations throughout Dutsin-Ma local government. The names of medicinal plants were recorded and samples of plants were collected. Screening was conducted to ensure that all selected plants were prescribed simultaneously by the entire number of 40 herbalists. 32 plants species screened out of 106 were identified and deposited at the herbarium, Department of Botany, Ahmadu Bello University, Zaria, Nigeria.

\section{Mode of the survey and data colection}

The survey was conducted orally as an interview. The herbalists were numbered 1-40. Plant material obtained from each of the herbalists was labelled and recorded. From the list of recorded plants (106), 32 species were found matching (commonly prescribed by all herbalists). The 32 species were identified and deposited at plants herbarium, Department of Botany, Ahmadu Bello University, Zaria, Nigeria. All data collection was done using record book and MS Excell sheet (fig.1).

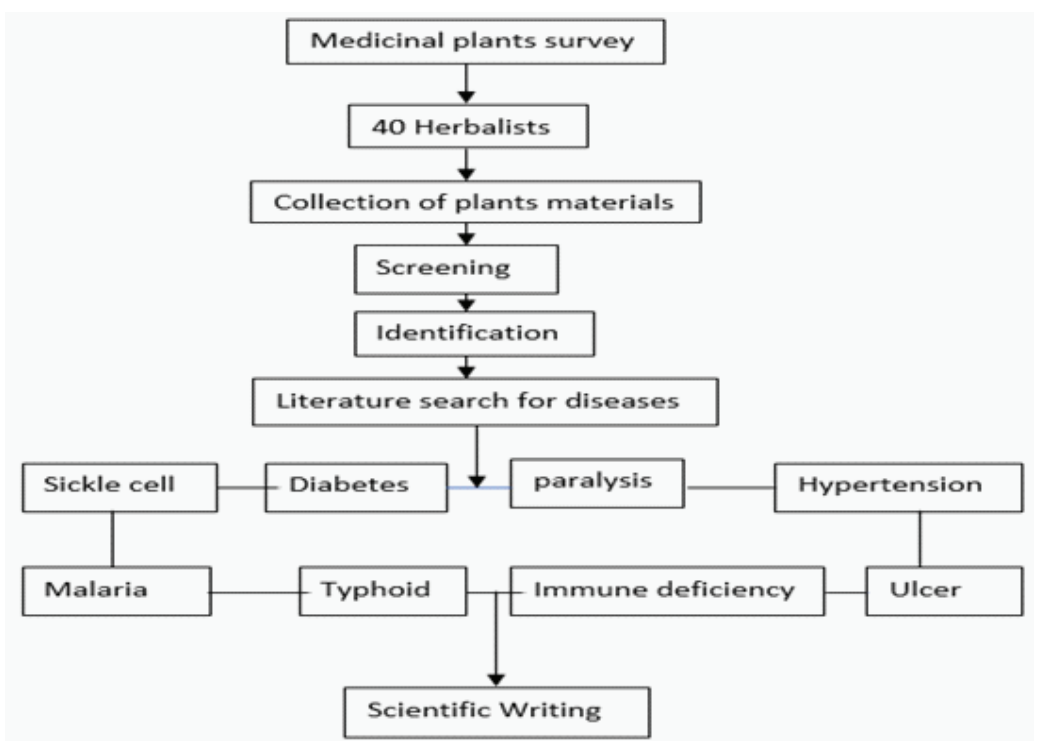

Figure 1

Flow chart of methodology 


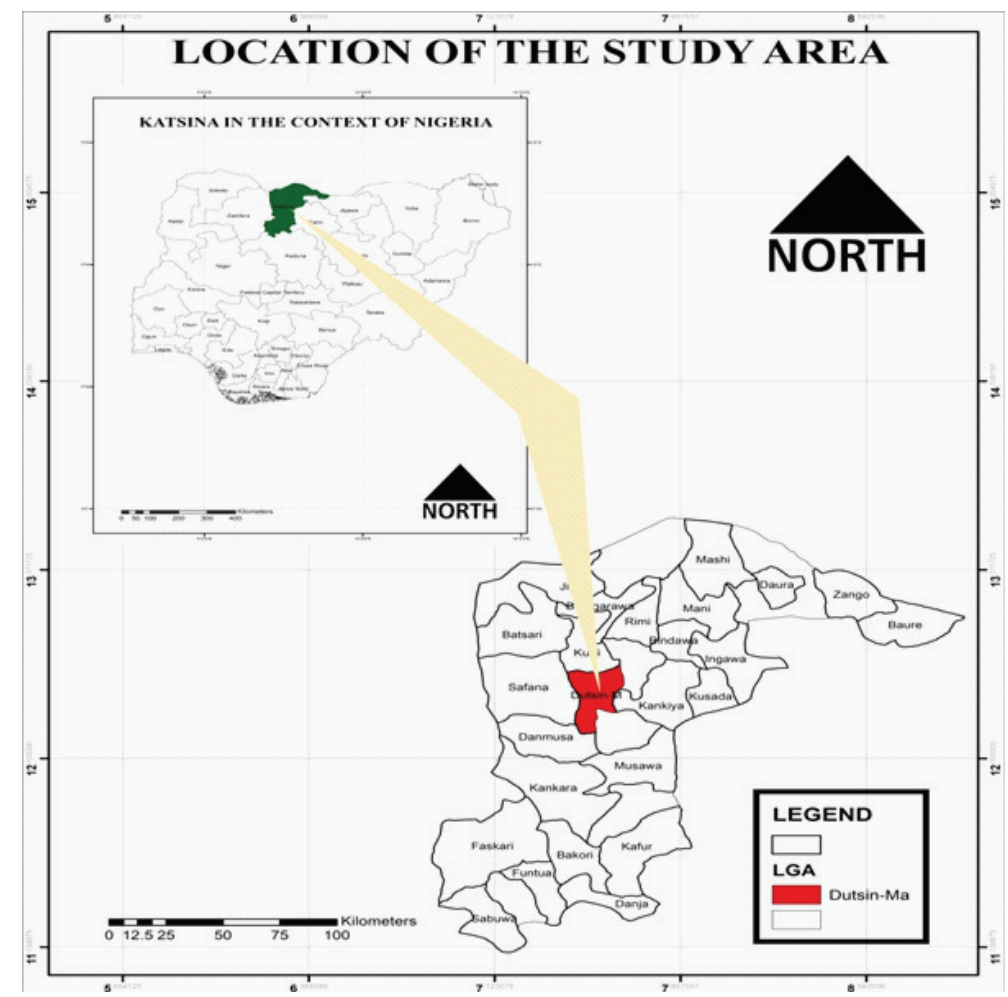

Figure 2

Map of study area

\section{Description of the study area}

Dutsin-Ma is one of the 34 local government areas in Katsina State, Nigeria $\left(12^{\circ} 27^{\prime} 18^{\prime \prime} N^{\prime}, 7^{\circ} 29^{\prime} 29^{\prime \prime E}\right)$ (fig.2). It has its headquarters located in the city of Dutsin-Ma with high population density. Most of the inhabitants of Dutsin-Ma consist essentially of Hausa and Fulani, although other Nigerian tribes can also be found. Most popular occupations in the area are farming, fishing, animal rearing and trading. Although the area has modern health facilities, according to interviewed herbalists, many inhabitants are said to consult them in most ailments.

\section{Malaria: medicinal plants, therapy and mana- gement}

Malaria, an infectious disease caused by Plasmodium falciparum due to female anopheles mosquito bite has been one of the health challenges disturbing many communities in Nigeria, including Dutsin-Ma area. As a result of many types of vegetation, malaria occurs in Nigeria almost yearly [4]. It was reported that in 2007, Nigeria was among the five countries that constitute half of the malarial cases in the world [5]. A study found high rate of malaria in Kano State, a town near Dutsin-Ma, where about $60.6 \%$ of the volunteers were found positive for Plasmodium falciparum [6]. A typical malaria symptoms may be vomiting, fever, headache and tiredness [7]. Development of a new plant-based antimalarial drug is necessary due to the fact that the resistance to existing medications has developed and post-threat to life, especially among children under five [8]. Medicinal plants can supply the quality of antimalarial drugs capable of tackling malarial infections. Traditional medicinal plants are used to treat fever and other symptoms of malaria, according to this survey. Plant-based therapies may be used as a monotherapy or combined therapy (multiherbal therapy). Mono-phytotherapy involves the use of a single medicinal plant species to treat, alleviate or manage diseases or ailments. Common plant parts used for medicinal purposes include leaves, flowers, stem bark and roots. In multiherbal therapy, several plant species are used to prepare common extract, which is used for treatment. For example, collective blend of Azadirachta indica, Cymbopogon citrates leaves, Carica papaya leaves, and Anticardium occidentale leaves are used as infusions in the treatment of malaria [4]. Common medicinal plants used to treat malaria in the study area are presented in table 1. 
Table 1.

Medicinal plants for treatment and management of malaria

\begin{tabular}{|c|c|c|c|c|}
\hline Botanical name & Local name & Family name & Part used & Preparation \\
\hline $\begin{array}{l}\text { Cochlerspernum } \\
\text { tinctorium }\end{array}$ & Rawaya & Cochlospermeceae & leaves & $\begin{array}{l}\text { dried, grinded and } \\
\text { soaked in water }\end{array}$ \\
\hline Erythrina senegalensis & Minjirya & Papilionaceae & leaves & $\begin{array}{l}\text { dried, grinded and } \\
\text { soaked in water }\end{array}$ \\
\hline Ficus thoningii & Chediya & Moraceae & leaves/stem bark & $\begin{array}{l}\text { dried, grinded and } \\
\text { soaked in water }\end{array}$ \\
\hline Azadirachta indica & Dogonyaro & Meliaceae & leaves/stem bark & $\begin{array}{l}\text { dried, grinded, boiled/ } \\
\text { soaked in water }\end{array}$ \\
\hline Carica papaya & Gwanda & Caricaceae & leaves & $\begin{array}{l}\text { dried, grinded, boiled/ } \\
\text { soaked in water }\end{array}$ \\
\hline Mangifera indica & Mangwaro & Anacardiaceae & leaves & $\begin{array}{l}\text { dried, grinded, boiled/ } \\
\text { soaked in water }\end{array}$ \\
\hline
\end{tabular}

\section{Plants used in sickle cell anemia}

Sickle cell disease is a genetic blood disorder in which haemoglobin in the blood appears in sickle shape. It renders patients to sickle cell crisis and exposes them to shortage of breath, weakness, dizziness with increasing heart rate [9]. It characteristically results in anaemia due to fragile nature of sickle shape red cell that rupture easily [9]. In African countries, traditional herbalists use medicinal plants and other naturally obtained compounds to treat tropical diseases, including sickle cell anaemia [10]. Studies have reported the use of many plants for the management of sickle cell anaemia including those that possess anti-sickling activities $[10,11]$. Currently applied treatments of sickle cell anaemia are quite expensive and often could not be afforded by rural dwellers. This called for more research into the alternative therapy that is readily available and accessible in the subSaharan Africa where the disease is endemic. Plants used in the management of sickle cell anaemia are presented in table 2 .

\section{Plants used in diabetes}

Diabetes can be described as a metabolic/hormonal disease characterized by hyperglycaemia partly due to inability of the body to produce adequate insulin, or cells in the body are not responding to the insulin, or both $[12,13]$. Typical symptoms include polyuria (frequent urination), polydipsia (frequent thirst) and polyphagia (frequent hunger) $[12,14]$. High amount of glucose in blood for prolong period without treatment might lead to some complications which may affect kidney, eyes, nerves and render the individual to the risk of cardiovascular diseases $[12,14]$. Three main types of diabetes mellitus are 1. insulin-dependent diabetes mellitus 2 . non-insulin-dependent diabetes mellitus and 3. gestational diabetes [12]. Many plants are used as hypoglycaemic agents in Africa and the survey has documented over 1,000 plants with hypoglycaemic activities $[15,16]$. Some of plants have hypoglycaemic activities tested in laboratory animals and humans [1620]. Alternative therapies are required because, despite of the availability of modern therapies, the number of diabetics increases worldwide [18]. Plant-based therapies provide promising compounds that lower blood glucose and therefore play important role as hypoglycaemic agents in diabetes. The medicinal plants used for the management of diabetes are shown in table 3.

\section{Anti-paralytic medicinal plants}

Paralysis results from the loss of the muscle movement

Table 2.

Medicinal plants for management of sickle cell anaemia

\begin{tabular}{|c|c|c|c|c|}
\hline Botanical name & Local name & Family name & Part used & Preparation \\
\hline Syzygium aromaticum & Kanunfari & Myrtaceae & buds/leaves & $\begin{array}{l}\text { dried and soaked in } \\
\text { water }\end{array}$ \\
\hline Carica papaya & Gwanda & Caricaceae & leaves & $\begin{array}{l}\text { dried, grinded, boiled/ } \\
\text { soaked in water }\end{array}$ \\
\hline Moringa oleifera & Zogale & Moringaceae & leaves & $\begin{array}{l}\text { dried, grinded, boiled/ } \\
\text { soaked in water }\end{array}$ \\
\hline
\end{tabular}


Table 3.

Medicinal plants for management of diabetes

\begin{tabular}{|c|c|c|c|c|}
\hline Botanical name & Local name & Family name & Part used & Preparation \\
\hline Anisopus mannii & Sakayau & Asclepiadaceae & stem and leaves & $\begin{array}{l}\text { dried and soaked in } \\
\text { water }\end{array}$ \\
\hline Guiera senegalensis & Sabara & Combretaceae & leaves & $\begin{array}{l}\text { dried, grinded boiled/ } \\
\text { soaked in water }\end{array}$ \\
\hline Annona senegalensis & Gwandar-daji & Annonaceae & stem-bark, root, leaves & $\begin{array}{l}\text { dried, grinded boiled/ } \\
\text { soaked in water }\end{array}$ \\
\hline Aristolochia albida & Dumandutse & Aristolochiaceae & leaves, stem, roots, rhizome & $\begin{array}{l}\text { dried, grinded boiled/ } \\
\text { soaked in water }\end{array}$ \\
\hline Anogeissus leiocarpus & Marke & Combretaceae & stem-bark & $\begin{array}{l}\text { dried and soaked in } \\
\text { water }\end{array}$ \\
\hline Bauhinia thonningii & Kalgo & Leguminosae & leaves, roots, stem bark & $\begin{array}{l}\text { dried, grinded boiled/ } \\
\text { soaked in water }\end{array}$ \\
\hline Carica papaya & Gwanda & Caricaceae & leaves, fruit pulp, seed & $\begin{array}{l}\text { dried, grinded boiled/ } \\
\text { soaked in water }\end{array}$ \\
\hline
\end{tabular}

of the body after the failure in message transmission from brain to the muscle [21]. Message transmission failure could be either complete or partial and may occur on one side or both sides of the body. Common reasons of paralysis are stroke, broken neck and the injury of spinal cord [22]. A study has reviewed 37 traditional medicinal plants used to cure problems related to paralysis [21]. Out of 37, eleven were reported to have anti-paralytic activity [21]. An ethnobotanical survey of medicinal plants in the Middle East has found 152 plant species from 58 families that have anti-paralytic activity [23]. In Africa, traditional medicinal plants are used to treat paralysis as well as problems pertaining nervous systems using indigenous plants (tab. 4). Traditional management of paralysis involves recovering from the paralyzed nerves thereby relieving pain associated with it while restoring movement and sensation [21]. Table 4 presents medicinal plants used for management of paralysis and associated problems.

\section{Medical plants in management of typhoid fever}

Typhoid is an infection caused by Salmonella typhi, a bacterium that mostly grow in the intestine [24]. Symptoms begin with fever, headache, abdominal pain and vomiting [25]. A report indicated that many plant species are used traditionally to manage typhoid fever in Nigeria [26]. Various plant secondary metabolites interfere with the feverish condition, still acting as an antimicrobial against the causative bacteria. The plants used for typhoid fever management are presented in table 5 .

Table 4.

Medicinal plants for management of paralysiss

\begin{tabular}{|c|c|c|c|c|}
\hline Botanical name & Local name & Family name & Part used & Preparation \\
\hline Aristolochia ringens & Dumandutse & Aristolochiaceae & root/stem/leaves & $\begin{array}{l}\text { dried, grinded and } \\
\text { soaked in water }\end{array}$ \\
\hline Leptadenia hastata & Yadiya & Asclepiadaceae & leaves & $\begin{array}{l}\text { dried, grinded and } \\
\text { soaked in water }\end{array}$ \\
\hline
\end{tabular}

Table 5.

Medicinal plants for management of typhoid

\begin{tabular}{lllll}
\hline Botanical name & Local name & Family name & Part used & Preparation \\
\hline Cymbopogon citratus & Tsauri & Poaceae & leaves & infusion \\
Ficus thoningii & Chediya & Moraceae & leaves & infusion \\
Commiphora africana & Durumi & Burseraceae & leaves & infusion \\
Cassia tora & Tafasar masar & Leguminosae & infusion \\
Prosopis africana & Kirya & Mimosaceae & leaves & infusion \\
\hline
\end{tabular}




\section{Anti-hypertensive plants}

Hypertension is a medical condition in which blood pressure in arteries is elevated [27]. It could either be primary (lifestyle and genetics) or secondary (certain diseases or disorders) [28]. Currently, there are no symptoms associated with hypertension, but prolonged hypertension has been linked to the risk of stroke, heart failure, peripheral vascular diseases, vision loss and chronic kidney failure [29-32]. Hypertension is the third cause of death worldwide [33]. The prevalence of hypertension is increasing, but the awareness, control and treatment has not been intensively promoted [33] and people continue dying in silence. Hypertension may result in complications such as brain damage, retinal artery damage, renal dysfunction, diabetes and cardiovascular diseases, disability and death [29-33]. In table 6, two plants are presented that are commonly used in this area. Although there are many other plants, Daniellia oliveri and endothelin, alcohol, non-steroidal antiinflammatory drugs) and mucosal defense has been stated as the main cause of ulcer [35]. Traditional medicines are used worldwide for the management of symptoms of gastric ulcers [36]. A study has confirmed the anti-ulcer properties of methanolic extract of Ulmus campestris stem bark in laboratory animals and concluded that it possesses antioxidants and protective substances against gastric ulcer [36]. Plausible explanation of the mechanism of action of these plants may involve balancing the action of aggressive factors and straightening mucosal defense, antioxidants and clearing of the pathogens responsible. Medicinal plants used for the management of ulcer are presented in table 7.

\section{Medical plants used in management of immu- nodeficiency diseases}

Immunodeficiency can be described as a state in

Table 6.

Medicinal plants for management of hypertension

\begin{tabular}{lllll}
\hline Botanical name & Local name & Family name & Part used & Preparation \\
\hline Daniellia oliveri & Maje & Leguminosae & roots & $\begin{array}{l}\text { dried, grinded and } \\
\text { soaked in water }\end{array}$ \\
Hibiscus sabdariffa & Zabo & Malvaceae & leaves/flowers & soaked in water \\
\hline
\end{tabular}

Table 7.

Medicinal plants for management of ulcer

\begin{tabular}{lllll}
\hline Botanical name & Local name & Family name & Part used & Preparation \\
\hline Citrullus lanatus & Kankana & Cucurbitaceae & fleshy center/seeds & raw consumption \\
Ziziphus mauritiana & Magarya & Rhamnaceae & fruit, leaves and roots dried and mixed with \\
micus sycomorus & Baure & Moraceae & leaves, stem bark & dried and mixed with \\
milk or honey
\end{tabular}

Hibiscus sabdariffa are frequently prescribed by herbalist interviewed.

\section{Plants for management in ulcer}

Ulcer results from the exposure to gastric juice in the stomach and breakdown of mucosal defense coupled with pathogenic overlapping [34]. The imbalance between reported aggressive factors (pep$\sin$ and gastric secretion, gastro-intestinal tract secretion, oxidants and free radicals, leukotriene, which the body is unable to fight disease-causing pathogens following compromise or impairment of the system. It occurs either by partial or complete impairment of the immune system and therefore prevents the body from fighting diseases [37]. It also rendered the body susceptible to disease causing agents such as viruses and bacteria [37]. Medicinal plants play key role in the production of immunomodulators, which enhance immune system to fight infections. Here, we present some plants used by traditional herbalist to manage immune deficiency diseases (tab. 8). 
Table 8.

Medicinal plants for management of immunodeficiency diseases

\begin{tabular}{|c|c|c|c|c|}
\hline Botanical name & Local name & Family name & Part used & Preparation \\
\hline Calotropis procera & Tumfafiya & Apocynaceae & leaves/roots & $\begin{array}{l}\text { dried, grinded and soaked } \\
\text { in water }\end{array}$ \\
\hline Ficus abustifolia & Yandi & Moraceae & leaves & $\begin{array}{l}\text { dried, grinded and soaked } \\
\text { in water }\end{array}$ \\
\hline Cymbopogon citratus & Tsauri & Poaceae & leaves/grass/roots & $\begin{array}{l}\text { dried, grinded and soaked } \\
\text { in water }\end{array}$ \\
\hline Cassia tora & Tafasa & Leguminosae & leaves & $\begin{array}{l}\text { dried, grinded and soaked } \\
\text { in water }\end{array}$ \\
\hline
\end{tabular}

Ethical approval: The conducted research is not related to either human or animal use.

\section{RESULTS}

In our study, we have listed 32 species of medicinal plants from 20 families that are used for the management and alternative therapy against common ailments such as malaria, diabetes, sickle cell anaemia, hypertension, ulcer, paralysis, typhoid fever and immune deficiency in Dutsin-Ma metropolis by 40 traditional herbalists (fig. 3 ). Of the total 32 plant species surveyed, 6 plants were found to be used for the treatment of malaria, 3 plants for the management of sickle cell anaemia, 7 plants for diabetes, 2 plants for paralysis, 5 plants for typhoid fever, 2 plants for hypertension, 3 plants for ulcer and 4 plants for immunerelated deficiency (fig. 4).

\section{DISCUSSION}

In this study, we have carried out ethnobotanical survey in Dutsin-Ma area involving 40 traditional herbalists. We have obtained 106 medicinal plants out of which we reported 32 plants based on the common prescription by the all herbalists involved in the study. Many plant materials are used for medicinal purposes as witnessed by this ethnobotanical survey. The practice of traditional system of medicine continues to gain wide acceptance due to minimal side effects, affordable cost, population growth and development of drug resistance for current therapies [38]. World Health Organization has projected that about $80 \%$ of the world population depend on herbal medicines for the treatment and management of various diseases [38].

Due to frequent malarial infections, the indigenous plants have been used for treating malaria (tab. 1). From the results of this survey, it can be seen that 40 traditional herbalists commonly prescribe six plant species: Cochlerspernum tinctorium, Erythrina senegalensis, Ficus thoningii, Azadirachta indica, Carica papaya and Mangifera indica to treat symptoms of malaria, including fever. Interviewed herbalists also confirmed the use of plant material for the management of fever associated with typhoid, malaria and other ailments.

The management of sickle cell anaemia using traditional medicinal plant has been reported elsewhere $[10,11]$. An independent study has revealed 102 species of plants possessing anti-sickling properties within the families of Euphorbiaceae and $\mathrm{Fa}$ baceae used to manage sickle cell diseases [39]. In present study, we have found three plants (Syzygium aromaticum, Carica papaya, Moringa oleifera) that are used locally for the management of sickle cell anaemia (tab. 2).

In spite of current available medications, the occurrence of diabetes mellitus increases worldwide and has become the seventh cause of death in the world [40].The search to safer and effective medications to tackle this problem is therefore very necessary. Results from table 3 shows that six plants: Anisopus mannii, Guiera senegalensis, Annona senegalensis, Aristolochia albida, Anogeissus leiocarpus, Bauhinia thonningii, Carica papaya are commonly prescribed for the treatment of high blood glucose and related complications. A study has observed the use of some of these medicinal plant families in Sokoto, a town in Northwestern Nigeria for their antidiabetic properties [41]. Natural products from 


\section{Families of plants involved in treatment of diseases}

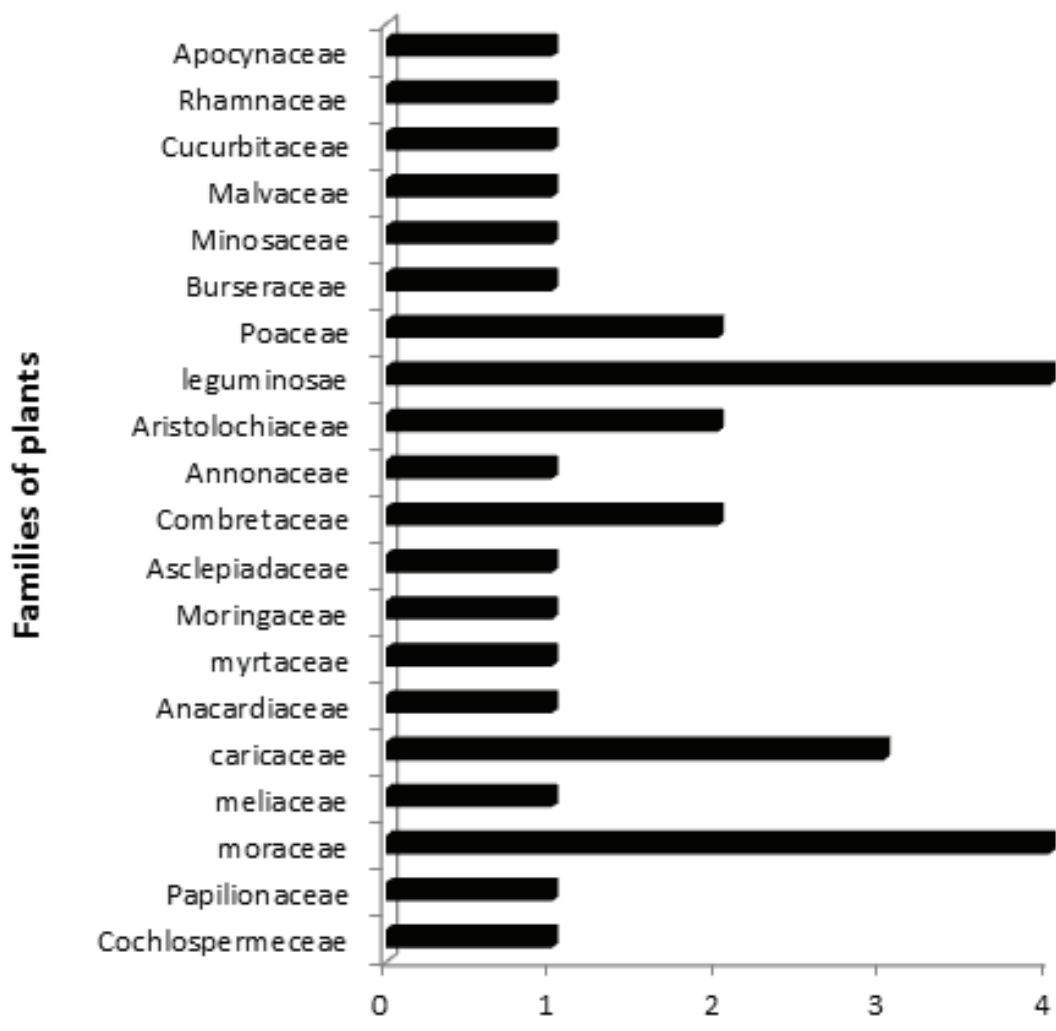

Number of diseases treated using the plants families

Figure 3

Families of plants involved in the treatment of diseases in study area

\section{Common diseases treated with use of medicinal plants}

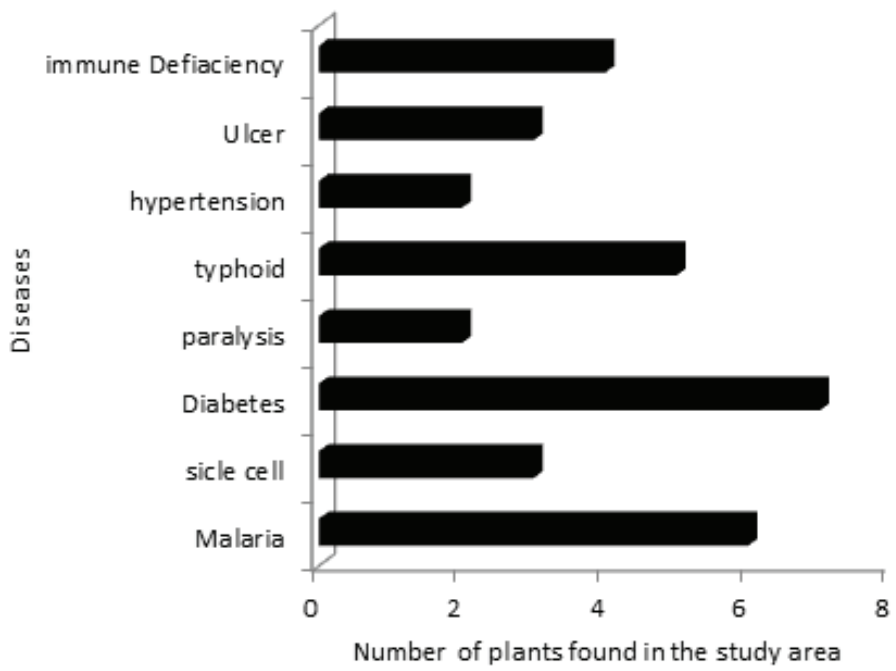

Figure 4

Common diseases treated by medicinal plants in study area 
plants have been reported to have a role in regulating carbohydrate metabolism by enhancing glucose uptake or increasing insulin sensitivity as a result of secondary metabolites [42].

The main challenge of paralysis is the restriction of the movement of nerves, probably due to their damage. The mechanism underlying the anti-paralytic activities of these medicinal plants may probably involve the restoring movement and sensation by reversing stroke, healing neck and spinal cord injuries.

Secondary plant metabolites function as antihypertensive agents in many plants. Thus, they are used traditionally to treat hypertension and its complications by obtaining plant preparations (tab. 6). Before the discovery of antibiotics, different plant preparations were used for the treatment of Salmonella typhi (tab. 5), the agent that causes typhoid fever. Antioxidants may well participate in protecting the gastro-intestinal tract [43] from the imbalance of mucosal defense and aggressive factors, interfering with factors that cause ulcer, including Helicobacter pylori. At the end, plants play important role in immunomodulation of the immune system, boosting the immune system to fight many infections [44].

\section{CONCLUSION}

Traditional medicinal plants provide the alternative therapy for the treatment and management of many diseases in the significant number of people in the population under direction of herbalists.

Herbal practitioners are still relevant to African healthcare system.

Plant material can provide alternative therapy at a lower cost.

Conflict of interest: Authors declare no conflict of interest.

\section{REFERENCES}

1. Boadu AA, Asase A. Documentation of herbal medicines used for the treatment and management of human diseases by some communities in southern Ghana. Evid Based Complement Alternat Med 2017; 2017:3043061 doi: http://dx:doi. org/10.1155/2017/3043061

2. Idu, M, Timothy O, Erhabor JO, Obiora EJ. Ethnobotanical study of Nnewi North local govern- ment area of Anambra State, Nigeria. Indian J Fundam Appl Life Sci 2005; 1:199-208. Available at http://www.cibtech.org/jls.htm

3. Xu DP, Li Y, Meng X, Zhou T, Zhou Y, Zheng J, et al. Natural antioxidants in foods and medicinal plants: extraction, assessment and resources. Int J Mol Sci 2017; 18:96. doi: http://dx:doi. org/10.3390/ijms 18010096

4. Adebayo JO, Krettli AU. Potential antimalarials from Nigerian plants. J Ethnopharmacol 2011; 133:289-302. doi: http://dx.doi.org/10.1016/j. jep.2010.11.024

5. World Health Organization. Malaria. http://www. who.int/news-room/fact-sheets/detail/malaria. Accessed $2^{\text {nd }}$ June 2019.

6. Dawaki S, Al-Mekhlafi HM, Ithoi I, Ibrahim J, Atroosh WM, Abdulsalam AM, et al. Is Nigeria winning the battle against malaria? Prevalence, risk factors and KAP assessment among Hausa communities in Kano State. Malar J 2016; 15:351. doi: http://dx.doi.org/10.1186/s12936-016-1394-3

7. Caraballo H. Emergency department management of mosquito-borne illness. Malaria, dengue, and west Nile virus. Emerg Med Pract 2014; 5:16.

8. World Health Organization. The use of antimalarial drugs. Report of a WHO informal consultation. Geneva 2001; 13-17. Available at https:// apps.who.int/iris/handle/10665/66961

9. National Heart, Lung, Blood Institute. Sickle Cell Disease. https://www.nhlbi.nih.gov/health/ health-topics/topics/sca. Accessed 24 $4^{\text {th }}$ May 2019.

10. Ameh SJ, Tarfa FD, Ebeshi BU. Traditional herbal management of sickle cell dnemia: lessons from Nigeria. Anem 2012; 1-9. doi: http://dx.doi. org/10.1155/2012/607436

11. Nurain IO, Bewaji CO, Johnson JS, Davenport RD, Zhang Y. Potential of three ethnomedicinal plants as antisickling agents. Mol Pharm 2017;14(1):172-182. doi: http://dx.doi. org/10.1021/acs.molpharmaceut.6b00767

12. Goldenberg R, Punthakee Z. Canadian Diabetes. Association Clinical Practice Guidelines Expert Committee. Definition, classification and diagnosis of diabetes, prediabetes and metabolic syn- 
drome. Can J Diabetes 2013;37 (Suppl.1):S8-S11. doi: http://dx.doi.org/10.1016/j.jcjd.2017.10.003

13. Adinortey MB, Agbeko R, Boison D, Ekloh W, Kuatsienu LE, Biney EE, et al. Phytomedicines used for diabetes mellitus in Ghana: a systematic search and review of preclinical and clinical evidence. Evid Based Complement Alternat Med 2019; 2019:6021209. doi: http://dx.doi. org/10.1155/2019/6021209

14. Adinortey MB, Gyan BE, Adjimani J, Nyarko P, Sarpong C, Tsikata FY, et al. Dyslipidaemia associated with type 2 diabetes with micro and macrovascular complications among Ghanaians. Indian J Clin Biochem 2011; 26(3):261-268. doi http://dx.doi.org/10.1007/s12291-010-0101-3

15. Upendra Rao M, Sreenivasulu M, Chengaiah B, Jaganmohan Reddy K. Madhusudhana Chetty C. Herbal medicines for diabetes mellitus: A review. Int J Pharmtech Res 2010;2(3):1883-1892.

16. Chikezie PC, Ojiako OA, Nwufo KC. Overview of anti-diabetic medicinal plants: The Nigerian research experience. J Diabetes Metab 2015; 6:546. doi: http://dx. doi.org/10.4172/2155-6156.1000546

17. Grover JK, Yadav S, Vats V. Medicinal plants of India with anti-diabetic potential. J Ethnopharmacol 2002; 81:81-100. doi: http://dx.doi. org/10.1016/s0378-8741(02)00059-4

18. Dey L, Attele AS, Yuan CS. Alternative therapies for type 2 diabetes. Altern Med Rev 2002; 7:4558.

19. Musabayane CT. The effects of medicinal plants on renal function and blood pressure in diabetes mellitus. Cardiovasc J Afr 2012; 23:462-468. doi: http://dx.doi.org/10.5830/CVJA-2012-025.

20. Jayawardena MHS, De Alwis NMW, Hettigoda V, Fernando DJS. A double blind randomize placebo controlled cross over study of an herbal preparation containing Salacia reticulate in the treatment of Type 2 diabetes. J Ethnopharmacol 2005; 96:215-218. doi: http://dx.doi.org/10.1016/j. jep.2004.10.026

21. Mikawlrawng K, Rani R, Kumar S, Bhardwaj AR, Prakash G. Anti-paralytic medicinal plants - review. J Trad Complement Med 2017; 8(1):4-10. doi: http://dx.doi.org/10.1016/j.jtc- me.2017.02.001

22. Paralysis. 2017. http://www.nhs.uk/Conditions/ paralysis/Pages/Causes.aspx. Accessed $2^{\text {nd }}$ Jun 2019.

23. Abu-Rabia A. Ethno-botanic treatments for paralysis (falij) in the Middle East. Chin Med 2012; 3:157-166. doi: http://dx.doi.org/10.4236/ $\mathrm{cm} .2012 .34025$

24. Wain J, Hendriksen RS, Mikoleit ML, Keddy KH, Ochiai RL. Typhoid fever. Lancet 2015; 385(9973):1136-1145. doi: http://dx.doi. org/10.1016/s0140-6736(13)62708-7

25. Crump JA, Mintz ED. Global trends in typhoid and paratyphoid fever. Clin Infect Dis 2010; 50(2):241-246. doi: http://dx.doi. org/10.1086/649541

26. Yomi FO, Mohammed I, Zurmi SR. Ethnomedicinal survey of anti-typhoid plants in Ijebu Ode local government area of Ogun State, Nigeria. Int J Sci Nat 2014; 5(2):332-336.

27. Naish J, Court DS. Medical sciences ( $\left.2^{\text {nd }} e d.\right)$. Elsevier 2014:562.

28. Poulter NR, Prabhakaran D, Caulfield M. Hypertension. Lancet 2015; 386(9995):801-812. doi: http://dx.doi.org/10.1016/S0140-6736(14)61468-9

29. Lackland DT, Weber MA. Global burden of cardiovascular disease and stroke: hypertension at the core. Can J Cardiol 2015; 31(5):569-571. doi: http://dx.doi.org/10.1016/j.cjca.2015.01.009

30. Mendis S, Puska P, Norrving B. Global atlas on cardiovascular disease prevention and control. World Health Organization 2011:38.

31. Hernandorena I, Duron E, Vidal JS, Hanon O. Treatment options and considerations for hypertensive patients to prevent dementia. Expert Opin Pharmacother 2017; 18(10):989-1000. doi: http:// dx.doi.org/10.1080/14656566.2017.1333599

32. Lau DH, Nattel S, Kalman JM, Sanders P. Modifiable risk factors and atrial fibrillation. Circulation 2017; 136(6):583-596. doi: http://dx.doi. org/10.1161/CIRCULATIONAHA.116.023163

33. Chockalingam A, Campbell NR, Fodor JG. Worldwide epidemic of hypertension. Can J 
Cardiol 2006; 22(7):553-555. doi: http://dx.doi. org/10.1016/s0828-282x(06)70275-6

34. Mejia A, Kraft WK. Acid peptic diseases: pharmacological approach to treatment. Expert Rev Clin Pharmacol 2009; 2(3):295-314. doi: http:// dx.doi.org/10.1586/ecp.09.8

35. Zakaria ZA, Abdul Hisam EE, Rofiee MS, Norhafizah M, Somchit MN, Teh LK et al. In vivo antiulcer activity of the aqueous extract of Bauhinia purpurea leaf. J Ethnopharmacol 2011; 137:1047-1054. http://dx.doi.org/10.1016/j. jep.2011.07.038

36. Boudaoud-Ouahmed H, Yous F, Ouaret N, Schini-Keirth VB, Djebbli N, Atmani D. Evaluation of gastroprotective, hepatoprotective and hypotensive activities of Ulmus campestris bark extract. Phytothérapie 2016; 14(4):229-240. doi: http:// dx.doi.org/10.1007/s10298-015-0982-7

37. British Society for Immunology. Immunodeficiency 2019. https://www.immunology.org/policy-and-public-affairs/briefings-and-positionstatements/immunodeficiency. Accessed $26^{\text {th }}$ May 2019.

38. World Health Organization. WHO monographs on selected medicinal plants. Volume 4. https:// www.who.int/medicines/areas/traditional/SelectMonoVol4.pdf. Accessed 20th November 2019.
39. Amujoyegbe OO, Idu M, Agbedahunsi JM, Erhabor JO. Ethnomedicinal survey of medicinal plants used in the management of sickle cell disorder in Southern Nigeria. J Ethnopharmacol 2016; 185:347-360. http://dx.doi.org/10.1016/j. jep.2016.03.042

40. World Health Organization. Diabetes. Retrieved from https://www.who.int/news-room/factsheets/detail/diabetes $20^{\text {th }}$ November 2019

41. Salihu ST, Bello L, Wara H S, Ali S. An ethnobotanical survey of antidiabetic plants used by Hausa-Fulani tribes in Sokoto, Northwest Nigeria. J Ethnopharmacol 2015; 172:91-99. doi: http:// dx.doi.org/10.1016/j.jep.2015.06.014

42. Prabhakar PK, Doble M. Mechanism of action of natural products used in the treatment of diabetes mellitus. Chin J Integr Med 2011; 17(8):563-574. doi: http://dx.doi.org/10.1007/s11655-011-0810-3

43. Halliwell B, Zhao K, Whiteman M. The gastrointestinal tract: a major site of antioxidant action? Free Radic Res 2000; 33:819-830. doi: http:// dx.doi.org/10.1080/10715760000301341

44. Nair A, Chattopadhyay D, Saha B. Plant-derived immunomodulators. In: Ahmad Khan MS, Ahmad I, Chattopadhyay D (eds.). New look to phytomedicine. $1^{\text {st }}$ ed. Cambridge. Academic Press, 2019:435-499. 